\title{
Tax Avoidance Sebagai Latar Belakang Dalam Memanfaatkan Tax Deductible Expense (Studi pada Perusahaan Manufaktur yang Terdaftar di BEI)
} Fitri Oktariani ${ }^{1}$ Putu Indrajaya Lembut ${ }^{2}$

\author{
Fakultas Ekonomi dan Bisnis Universitas Ma Chung
}

\section{A R T I C L E I N F O}

\section{Article history:}

Received 20 Desember 2018

Revised 25 Desember 2018

Accepted 27 Desember 2018

\section{Key words:}

Tax Deductible Expense, Tax Avoidance, Cost of Debt, Bursa Efek Indonesia

\begin{abstract}
A B S T R A C T
This study aims to test and prove empirically the effect of tax avoidance on the cost of debt. The research population is a company listed on the Indonesia Stock Exchange with a sample of companies in the manufacturing category during 2012 to 2017, which is as many as 50 sample companies. Sampling uses purposive sampling and the data analysis method used is a simple linear regression method. The results of this study prove that tax avoidance has a positive effect on the cost of debt. Based on the results of testing this study, it can be concluded that the company will always use a tax deductible expense in its efforts to conduct tax avoidance regardless of the tax rate that has been imposed by the government. Thus, the government should consider further policies by focusing more on regulating the recognition of tax deductible expenses, rather than issuing a policy of reducing back rates, especially for corporate taxpayers.
\end{abstract}

\begin{abstract}
A B S T R A K
Penelitian ini bertujuan untuk menguji dan membuktikan secara empiris pengaruh tax avoidance terhadap cost of debt. Populasi penelitian adalah perusahaan yang terdaftar di Bursa Efek Indonesia dengan sampel perusahaan dalam kategori manufaktur selama tahun 2012 sampai dengan tahun 2017, yaitu sebanyak 50 perusahaan sampel. Pengambilan sampel menggunakan purposive sampling dan metode analisis data yang digunakan adalah regresi linear sederhana. Hasil penelitian ini membuktikan bahwa tax avoidance berpengaruh positif terhadap cost of debt. Berdasarkan hasil pengujian penelitian ini, dapat disimpulkan bahawa bahwa perusahaan akan selalu menggunakan tax deductible expense dalam usahanya untuk melakukan tax avoidance berapapun tarif pajak yang telah dikenakan oleh pemerintah. Dengan demikian, pemerintah sebaiknya mempertimbangkan kebijakan lanjutan dengan lebih fokus kepada pengaturan terhadap pengakuan tax deductible expense, daripada menerbitkan kebijakan penurunan tarif kembali khususnya bagi wajib pajak badan.
\end{abstract}

\section{INTRODUCTION}

Telah menjadi program pemerintah untuk berperan aktif dalam membantu menumbuhkan iklim usaha, yaitu mendorong investasi dan economic sustainability dengan tetap berpegang pada prinsip keadilan, kemudahan, dan efisiensi administrasi, serta peningkatan dan optimalisasi penerimaan negara dengan tetap mempertahankan self-assessment system. Demi memenuhi tujuan ini, berbagai kebijakan pemerintah sudah dilaksanakan, termasuk perubahan pajak terbaru di
Indonesia, yaitu UU No. 36 Tahun 2008 yang merupakan perubahan dari UU No. 17 Tahun 2000 dengan mengusung penurunan tarif pajak penghasilan badan (tax cut rate).

Tarif pajak penghasilan badan pada awalnya menggunakan tarif pajak progresif yang dikenakan secara berjenjang terhadap Penghasilan Kena Pajak (PKP) sesuai dengan UU No. 17 Tahun 2000, yaitu sebesar 10\% untuk PKP > Rp50 juta, 15\% untuk PKP antara Rp50 juta s/d Rp100 juta, dan 30\% sebagai tarif marginal untuk PKP > Rp100 juta.

\footnotetext{
* Corresponding author, email address: 1fitri.oktariani@machung.ac.id
} 
Pada tahun 2009 diturunkan menjadi 28\% dengan menggunakan tarif tunggal yang berarti berapapun tingkat laba suatu perusahaan akan dikenakan tarif pajak yang sama, dan pada tahun 2010 diturunkan kembali menjadi 25\% yang berlaku efektif sejak tahun 2011.

Penurunan tarif tersebut diharapkan dapat meningkatkan kesadaran perusahaan untuk lebih patuh dalam membayar pajak, sehingga akan berdampak pada meningkatnya penerimaan negara. Namun nyatanya, target penerimaan negara dari sektor perpajakan di tahun 2017 sulit untuk direalisasikan, sama halnya seperti di tahun 2016. Hal ini tercermin dari data kinerja perpajakan yang diungkapkan oleh Ronny P. Sasmita sebagai pengamat ekonomi Indonesia, yaitu pada kuartal I tahun 2017 mencatatkan setoran pajak sebesar Rp222 triliun. Jumlah tersebut hanya mencapai 16,98\% dari target APBN 2017 yang dipatok sebesar Rp1.307,6 triliun (www.liputan6.com). Demikian pula data terkini dari Direktorat Jenderal Pajak juga mengemukakan hal yang sama, seperti terlihat dalam Tabel 1, berikut:
Tabel 1. Penerimaan Pajak Tahun 2017

\begin{tabular}{|c|c|c|c|c|c|c|}
\hline No. & Jenis Pajak & $\begin{array}{c}\text { APBNP } \\
2017\end{array}$ & $\begin{array}{l}\text { Real. } \\
2016\end{array}$ & $\begin{array}{l}\text { Real. } \\
2017\end{array}$ & \begin{tabular}{|c|}
$\%$ \\
Growth \\
Real \\
2017
\end{tabular} & \% Capai \\
\hline$A$ & PPh Non Migas & 742,20 & 630,11 & 596,58 & $-5,32 \%$ & $80,38 \%$ \\
\hline & - diluar TA \& Reval & & 507,42 & 584,58 & $15,21 \%$ & \\
\hline $\mathrm{B}$ & PPN \& PPnBM & 457,48 & 412,21 & 480,72 & $16,62 \%$ & $101,10 \%$ \\
\hline $\mathrm{C}$ & PBB & 15,41 & 19,44 & 16,77 & $\mid-13,74 \%$ & $108,82 \%$ \\
\hline $\mathrm{D}$ & Pajak Lainnva & 8,70 & 8.10 & 6,74 & $-16,80 \%$ & $77,45 \%$ \\
\hline$E$ & PPh Migas & 42,77 & 36,10 & 50,32 & $39,39 \%$ & $120,68 \%$ \\
\hline & tal Penerimaan DJP & 1.283 .57 & $1.105,97$ & $1.151,13$ & $4,08 \%$ & $89,68 \%$ \\
\hline \multicolumn{2}{|c|}{ Total di luar TA \& Reval } & & 983,28 & $1.139,13$ & $\mid 15,58 \%$ & \\
\hline
\end{tabular}

Sumber: Direktorat Jenderal Pajak 2018

Dari Tabel 1 dapat dilihat bahwa setoran pajak sebesar Rp1.151,13 triliun ternyata hanya mencapai 89,68\% dari target penerimaan APBN-P Tahun 2017. Artinya, jumlah penerimaan negara dari sektor pajak penghasilan ini masih tetap belum dapat memenuhi target penerimaan APBN-P Tahun 2017 meskipun sudah ada peningkatan yang signifikan. Jumlah tersebut telah menggambarkan pertumbuhan penerimaan di luar tax amnesty dan revaluasi aset sebesar 15,85\%. Berdasarkan persentase pertumbuhan tersebut dapat dijabarkan lebih lanjut mengenai besarnya kontribusi pertumbuhan penerimaan pajak dari masingmasing jenis pajak penghasilan, seperti dalam Tabel 2, berikut:

Tabel 2. Realisasi Penerimaan Pajak Tahun 2017

\begin{tabular}{|c|c|c|c|c|c|c|c|c|}
\hline & & & & & & & \multicolumn{2}{|c|}{ (triliun rupiah) } \\
\hline \multirow{3}{*}{ No. } & \multirow{3}{*}{ Jenis Pajak } & APBN-P & \multicolumn{6}{|c|}{ Realisasi s.d. 31 Desember } \\
\hline & & 2017 & 3016 & 3017 & $\Delta \%$ & $\Delta \%$ & $\%$ Penc. & $\%$ Penc. \\
\hline & & 2017 & 2016 & 2017 & $2015-2016$ & $2016-2017$ & 2016 & 2017 \\
\hline A & PPh Non Migas & 742,20 & 630,11 & 596,58 & 14,02 & $(5,32)$ & 76,89 & 80,38 \\
\hline & 1. PPh Ps 21 & 148,05 & 109,64 & 117,76 & $(4,22)$ & 7,41 & 84,77 & 79,54 \\
\hline & 2. PPh Ps 22 & 11,06 & 11,35 & 16,27 & 33,90 & 43,33 & 115,82 & 147,05 \\
\hline & 3. PPh Ps 22 Impor & 52,54 & 37,98 & 43,16 & $(5,67)$ & 13,64 & 87,26 & 82,14 \\
\hline & 4. PPh Ps 23 & 36,39 & 29,14 & 34,01 & 4,52 & 16,69 & 92,50 & 93,45 \\
\hline & 5. PPh Ps $25 / 29$ OP & 19,94 & 5,31 & 7,81 & $(35,66)$ & 46,91 & 18,45 & 39,16 \\
\hline & 6. PPh Ps $25 / 29$ Badan & 242,66 & 171,60 & 208,25 & $(7.35)$ & 21,36 & 45,62 & 85.82 \\
\hline & 7. PPh Ps 26 & 55,12 & 43,23 & 50,92 & $(10,35)$ & 17.78 & 79,34 & 92,39 \\
\hline & 8. $\mathrm{PPh}$ Final & 156,18 & 117,68 & 106,32 & $(1,66)$ & $(9,65)$ & 80,77 & 68.07 \\
\hline & 9. PPh Non Migas Lainnya & 20,24 & 104,18 & 12,08 & $54.923,50$ & $(88,40)$ & $49.131,78$ & 59,69 \\
\hline $\mathrm{B}$ & PPN dan PPnBM & 475,48 & 412,21 & 480,72 & $(2,71)$ & 16,62 & 86,92 & 101,10 \\
\hline & 1. PPN Dalam Negeri & 328,07 & 273,00 & 314,34 & $(2,50)$ & 15,14 & 85,74 & 95,81 \\
\hline & 2. PPN Impor & 132,36 & 122,77 & 149,03 & $(5,65)$ & 21,39 & 87,28 & 112,60 \\
\hline & 3. PPnBM Dalam Negeri & 10,64 & 11,81 & 13,29 & 27,09 & 12,55 & 112,47 & 124,90 \\
\hline & 4. PPnBM Impor & 4,08 & 4,30 & 3,80 & 7,16 & $(11,62)$ & 99,13 & 93,12 \\
\hline & 5. PPN/PPnBM Lainnya & 0,34 & 0,33 & 0,26 & 19,30 & $(21,40)$ & 98,75 & 76,59 \\
\hline $\mathrm{C}$ & PBB & 15,41 & 19,44 & 16,77 & $(33,53)$ & $(13,74)$ & 109.79 & 108.82 \\
\hline $\mathrm{D}$ & Pajak Lainnya & 8,70 & 8,10 & 6,74 & 45,55 & $(16,86)$ & 109,31 & 77,45 \\
\hline $\mathrm{E}$ & PPh Migas & 41,77 & 36,10 & 50,32 & $(27,33)$ & 39,39 & 99,32 & 120,46 \\
\hline & Total P enerimaan DJP & $1.283,57$ & $1.105,97$ & $1.151,13$ & 4,25 & 4,08 & 81,61 & 89.68 \\
\hline
\end{tabular}

Sumber: Direktorat Jenderal Pajak 2018 
Data (tabel 2) menunjukkan ternyata penerimaan pajak yang paling banyak berkontribusi meningkatkan penerimaan APBN-P adalah dari PPh Orang Pribadi, yaitu sebesar 46,91\%, sementara PPh Badan hanya meningkat sebesar 21,36\%. Kondisi ini mengindikasikan bahwa besar kemungkinan Wajib Pajak Badan masih melakukan praktik-praktik tax avoidance. Wajib Pajak Badan masih belum termotivasi untuk secara sukarela patuh dalam membayarkan pajak terutangnya, karena pungutan wajib yang dilakukan oleh pemerintah sampai saat ini dinggap lebih merupakan beban yang akan mengurangi tingkat labanya secara signifikan daripada harus memanfaatkan tax amnesty. Hal ini karena berapapun tarif pajak yang dikenakan, meskipun tarif PPh Badan sudah diturunkan menjadi 25\% tetap saja perusahaan akan melakukan perencanaan pajak agar beban pajak yang akan dikeluarkan dapat ditekan seminimal mungkin.

Tax avoidance dapat diartikan sebagai bagian dari perencanaan pajak (tax planning) yang dilakukan dengan tujuan meminimalkan jumlah pajak terutang perusahaan (penghematan pajak). Pengukuran tax avoidance menurut sejumlah besar penelitian sebelumnya seperti, Siegfried (1972), Dyreng (2008), dan Rego (2003) menggunakan GAAP ETR (General Accepted Accounting Principle Effective Tax Rate) yang dapat menggambarkan perbandingan antara beban pajak penghasilan badan untuk suatu perusahaan pada periode tertentu dengan jumlah pendapatan sebelum pajaknya, sehingga akan terlihat jelas persentase besarnya pajak yang dibayarkan dibandingkan dengan persentase pendapatan yang diperoleh selama satu periode. Dengan demikian, peneliti menggunakan pengukuran yang sama dengan penelitian terdahulu, dikarenakan GAAP ETR cukup relevan dalam menjelaskan tujuan dari penelitian tersebut.

Tax avoidance dapat juga dilakukan secara legal dengan memanfaatkan ketentuan perpajakan yang berlaku (Lim, 2011), dan secara umum memanfaatkan kelemahan-kelemahan hukum pajak (loopholes) yang ada dengan argumen tanpa melanggar hukum perpajakan (Dyreng, 2008) ataupun dengan memanfaatkan pengeluaran yang dapat dikurangkan dari penghasilan bruto (deductible expense). Intinya menata pengeluaran yang mempunyai hubungan langsung dengan usaha yang pembebanannya dapat dilakukan dalam tahun pengeluaran atau selama masa manfaat atas pengeluaran tersebut menjadi lebih besar (Resmi, 2016). Salah satu pengeluaran/biaya (deductible expense) yang diperkenankan sebagai pengurang pajak menurut Undang-Undang Perpajakan No.36/2008 Pasal 6 ayat (1) adalah dengan menggunakan bunga pinjaman yang timbul dari aktivitas peminjaman dana ke pihak lain. Penjelasannya terdapat pada Peraturan Menteri Keuangan (PMK) No.169/PMK.010/2015 pasal 2 ayat (1), menyebutkan bahwa bunga pinjaman yang dapat diakui sebagai biaya adalah sebesar bunga atas utang yang perbandingannya terhadap modal, yaitu setinggi-tingginya 4:1 (empat berbanding satu) dengan mempertimbangkan kemungkinan terjadinya financial distress. Dalam hal ini, financial distress merupakan suatu kondisi dimana perusahaan mengalami kesulitan keuangan untuk memenuhi kewajiban-kewajibannya, terutama yang ditimbulkan oleh aktivitas pinjaman/utang.

Oleh sebab itu, pemanfaatan deductible expense dalam melakukan praktik tax avoidance seringkali mendapat sorotan yang kurang baik dari Direktorat Jenderal Pajak (DJP), karena dianggap memiliki konotasi yang negatif secara etis (Masri dan Martani, 2012), yaitu dapat diartikan tidak jujur dalam membayar pajak yang sudah pasti melanggar pemenuhan prinsip kepatuhan materiil mengenai kewajiban pajak, meskipun hal ini secara hukum tidak dilarang. Sifat tax avoidance yang sah menurut hukum ini membuat perusahaan tidak dapat dijatuhi sanksi langsung, sanksi dapat diberikan apabila Undang-Undang Perpajakan telah secara jelas mengatur batasan-batasan dalam tax avoidance. Hal ini sekaligus mencerminkan isi dari UU Perpajakan di Indonesia yang kurang kuat dan masih memberikan celah yang memungkinkan dilakukannya pelanggaran.

Kaitan dari pemanfaatan deductible expense dengan menggunakan bunga pinjaman tentu saja dengan pinjaman/utang dari perusahaan itu sendiri. Adapun teori yang membahas mengenai permasalahan tersebut adalah Teori Modigliani Miller menyatakan bahwa utang telah banyak digunakan sebagai pilihan sumber dana eksternal oleh perusahaan karena dapat memperoleh manfaat ekonomis berupa pengurangan pajak melalui bunga pinjaman (Miller, 1977), artinya semakin tinggi penggunaan utang, semakin besar pula bunga pinjaman yang akan membuat pajak terutang perusahaan yang harus dibayar turun, meskipun tingkat pengembalian yang timbul semakin tinggi.

Menurut Bathala dan Carlson (1995), pembebanan bunga pinjaman biasanya dikaitkan dengan leverage perusahaan, yaitu rasio keuangan 
yang menggambarkan hubungan antara utang terhadap aset perusahaan. Sedangkan dalam penelitian ini, pengukuran bunga pinjaman menggunakan pengukuran yang mengacu pada penelitian Graham dan Tucker (2006), dan Lim (2011), yaitu cost of debt. Biaya utang (cost of debt) menurut Pittman dan Fortin (2004) adalah "the interest rate on the firm's debt" yang artinya setiap beban bunga yang harus dibayarkan oleh perusahaan dalam satu periode tertentu. Dengan demikian, pengukuran bunga pinjaman dengan menggunakan cost of debt dianggap lebih relevan dalam menginterpretasikan tujuan dari penelitian ini, karena hanya melihat dari sudut pandang beban dari pinjaman saja yang benar-benar harus dibayar oleh perusahaan.

Berkaitan dengan perilaku Wajib Pajak Badan yang akan selalu memanfaatkan kelemahan dari UU Perpajakan untuk melakukan tax avoidance meskipun sudah ada banyak perubahan peraturan dalam UU Perpajakan (Tax Reform Act) yang dilakukan oleh pemerintah untuk membangun kepercayaan perusahaan dengan tujuan menumbuhkan kesadaran patuh dalam membayar pajak, baik secara formil maupun materiil ini, telah dikembangkan teori Psikologis Fiskal yang pertama kali dikemukakan oleh Schmolder (1959). Teori inilah yang menghubungkan ekonomi dan pendekatan perilaku, yaitu dengan menekankan bahwa rendahnya motivasi wajib pajak untuk membayar pajak dikarenakan wajib pajak tersebut tidak merasakan manfaat dari membayar pajak dalam bentuk moneter atau barang-barang publik. Teori Psikologis Fiskal juga memberikan wawasan mengenai cara orang berperilaku dalam situasi ekonomi dengan mengeksplorasi efek dari isu-isu ekonomi dan tindakan pemerintah tentang sikap masyarakat dalam upaya untuk mendorong perilaku positif dalam mematuhi peraturan pajak. Teori ini menekankan pentingnya kebijakan positif yang dikembangkan oleh pemerintah untuk meningkatkan kerjasama antara pembayar pajak dengan pemerintah, salah satunya adalah dengan pengurangan tarif pajak yang dapat menstimulus perilaku positif dari wajib pajak untuk patuh terhadap pajak.

Begitupun, sampai saat ini di Indonesia dapat dikatakan bahwa pemerintah sudah melakukan kebijakan positif dengan menurunkan tarif pajak penghasilan untuk Wajib Pajak Badan demi menumbuhkan kesadaran Wajib Pajak Badan agar patuh dalam melakukan pembayaran pajak, sehingga diharapkan tindakan tax avoidance yang selalu dilakukan oleh perusahaan dan akan berdampak pada penurunan penerimaan APBN-P dari sisi pajak penghasilan dapat berkurang. Kebijakan tersebut sudah berjalan kurang lebih 7 (tujuh) tahun sampai dengan sekarang, ditambah lagi pemerintah merencanakan untuk membuat kebijakan baru di tahun-tahun mendatang dengan menurunkan tarif pajak badan sampai dengan 10\% (www.ortax.org). Jadi apabila perusahaan masih saja melakukan tax avoidance dengan memanfaatkan celah dari Undang-Undang Perpajakan (tax deductible expense), maka dapat dikatakan tujuan pemerintah untuk berperan aktif dalam membantu menumbuhkan iklim usaha untuk mengoptimalkan penerimaan negara melalui penurunan tarif pajak ini masih belum efektif. Selain itu, peneliti juga ingin mengemukakan masalah pentingnya kebijakan-kebijakan perpajakan baru yang dibuat oleh pemerintah agar dapat membangun rasa percaya antara masyarakat dengan pemerintah, sehingga memberikan dampak jangka panjang yang saling menguntungkan.

Penelitian ini juga mengacu pada beberapa penelitian terdahulu, seperti Masri dan Martani (2012) yang membuktikan bahwa tax avoidance berpengaruh positif terhadap cost of debt, selain itu struktur kepemilikan keluarga juga dapat memperkuat pengaruh positif tax avoidance terhadap cost of debt. Adapun penelitian Purwanti (2014) yang memiliki hasil yang tidak konsisten dengan penelitian sebelumnya, yaitu membuktikan bahwa tax avoidance tidak berpengaruh signifikan terhadap cost of debt, dan juga perubahan tarif pajak ternyata tidak mampu memoderasi pengaruh tax avoidance terhadap cost of debt. Sedangkan penelitian Kovermann (2018) telah membuktikan bahwa tax avoidance justru meningkatkan kemampuan perusahaan dalam melunasi utang dan task risk berpengaruh signifikan terhadap cost of debt perusahaan.

Berdasarkan hasil penelitian yang berbedabeda dari penelitian terdahulu, maka peneliti menganalisis bahwa pengukuran dari variabel penelitian tidak dapat disamakan, mengingat tujuan dari penelitian yang juga tidak sama. Sehingga, peneliti memfokuskan pengukuran variabel yang dapat merepresentasikan penggunaan tax deductible expense, artinya beban yang akan dikeluarkan oleh perusahaan saja terkait kepentingan perusahaan untuk meningkatkan efektifitas beban pajaknya (tax avoidance).

Berdasar isu di latar belakang dan data yang ada, maka tujuan penelitian ini adalah membuktikan pengaruh tax avoidance terhadap cost of debt dalam periode tarif pajak badan sudah lebih 
rendah daripada periode sebelumnya dari perusahaan-perusahaan yang telah go public di bidang manufaktur.

\section{THEORETICAL FRAMEWORK AND HYPOTHESES \\ 2.1 Landasan Teori}

\subsubsection{Teori Struktur Modal (Capital Structure)}

Struktur modal diartikan sebagai perimbangan atau perbandingan antara jumlah utang dengan modal sendiri (Riyanto, 2011). Berdasarkan definisi tersebut dapat dikatakan bahwa struktur modal berkaitan dengan sumber pendanaan. Dana yang berasal dari utang mempunyai biaya dalam bentuk bunga pinjaman. Menurut Titman dan Wessels (1988), perusahaan akan memilih sumber dana dengan biaya yang paling rendah, yaitu utang. Pemilihan ini dikatakan memiliki biaya yang paling rendah karena biaya bunga yang harus ditanggung lebih kecil dari laba yang diperoleh dari pemanfaatan utang tersebut.

\subsubsection{Teori Modigliani Miller Proposisi II}

Teori Mogdiliani-Miller Preposisi II tahun 1963 ini menjelaskan bahwa nilai perusahaan yang memiliki utang akan lebih tinggi daripada nilai perusahaan yang tidak memiliki utang. Teori ini juga mengatakan apabila ada dua perusahaan yang menghasilkan laba yang sama, yang satu tidak menggunakan utang dan perusahaan yang satunya menggunakan utang, pajak penghasilan yang dibayarkan tidak akan sama. Perusahaan yang menggunakan utang akan membayar pajak lebih kecil dibandingkan dengan perusahaan yang tidak menggunakan utang dan bisa menghemat pajak, maka laba yang akan dikembalikan kepada investor otomatis bertambah, sehingga nilai perusahaan (firm value) akan ikut naik.

\subsubsection{Teori Psikologis Fiskal (Pshycological Fiscal Theory)}

Menurut Schmolder (1959), teori psikologis fiskal menghubungkan ekonomi dan pendekatan perilaku dengan menekankan rendahnya motivasi wajib pajak untuk membayar pajak disebabkan wajib pajak yang tidak merasakan manfaat dari membayar pajak. Kotler, et al (2013) menyatakan bahwa tingkat kepatuhan sukarela wajib pajak lebih dipengaruhi oleh kepercayaan wajib pajak terhadap pemerintah. Sedangkan Akerlof (1982) mendeskripsikan hubungan antara wajib pajak dengan otoritas pajak sebagai kontrak implisit, sehingga akan menimbulkan ikatan emosional yang kuat. Persepsi wajib pajak terhadap pemerintah penting karena hubungan diantara wajib pajak dengan otoritas pajak adalah sebuah kontrak dengan interaksi yang kompleks diantara wajib pajak dan pemerintah dalam membangun hubungan timbal balik yang adil (Feld dan Frey, 2002).

Dengan demikian, teori ini memberikan gambaran atas kesediaan wajib pajak dalam membayar pajak akan dipengaruhi oleh pandangan wajib pajak terhadap pajak itu sendiri. Apabila wajib pajak percaya bahwa pemerintah telah mengalokasikan pajak yang telah mereka bayarkan dengan baik disertai dengan sistem pemungutan yang adil, maka wajib pajak cenderung untuk tidak melakukan penggelapan pajak (tax avoidance).

\subsection{Resistensi Pajak}

Perlawanan terhadap pajak yang dilakukan wajib pajak merupakan hambatan dalam pemungutan pajak, baik yang disebabkan oleh kondisi negara dan masyarakat maupun oleh usaha-usaha wajib pajak yang mempersulit pemasukan pajak sebagai sumber penerimaan negara. Ada dua bentuk perlawanan pajak yang dilakukan oleh warga negara menurut Brotihardjo (1993), yaitu:

1. Perlawanan Pasif, meliputi hambatanhambatan yang mempersulit pemungutan pajak yang erat hubungannya dengan struktur ekonomi suatu negara, perkembangan intelektual dan moral penduduk, serta sistem dan cara pemungutan pajak itu sendiri.

2. Perlawanan Aktif, meliputi semua usaha dan perbuatan yang secara langsung ditujukan kepada fiskus dan bertujuan untuk menghindari pajak.

Dalam perlawanan aktif, ada beberapa cara yang dapat digunakan untuk menghindari pajak, yakni:

1. Tax avoidance (penghindaran pajak)

Adalah upaya penghindaran pajak yang dilakukan secara legal dan aman bagi wajib pajak, karena tidak bertentangan dengan ketentuan perpajakan. Metode yang digunakan cenderung memanfaatkan kelemahan-kelemahan Undang-Undang (grey area).

2. Tax Evasion (penggelapan atau penyelundupan pajak)

Adalah upaya wajib pajak menghindari pajak terutang secara legal dengan cara menyembunyikan keadaan yang sebenarnya. Cara ini tidak aman bagi wajib pajak, karena 
metode yang digunakan tidak berada dalam koridor Undang-Undang Perpajakan.

3. Tax Saving (penghematan pajak)

Adalah upaya wajib pajak mengelak utang pajaknya dengan jalan menahan diri untuk tidak membeli produk-produk yang ada pajak pertambahan nilainya, atau dengan sengaja mengurangi jam kerja atau pekerjaan yang dapat dilakukannya, sehingga penghasilannya menjadi kecil dan dengan demikian terhindar dari pengenaan pajak penghasilan yang besar.

\subsection{Biaya Utang (Cost of debt)}

Biaya modal memperlihatkan tingkat minimum pengembalian yang harus diterima dari suatu investasi seperti penganggaran modal untuk memastikan agar nilai perusahaan tidak turun (Brigham dan Houston, 2013). Berdasarkan hal tersebut, jika dilihat dari sudut pandang perusahaan, cost of capital dapat diartikan sebagai biaya yang dikeluarkan oleh perusahaan untuk memperoleh sumber dana yang dibutuhkan. Biaya tersebut dibagi lagi menjadi dua, yaitu: biaya modal utang (cost of debt) yang merupakan biaya yang berasal dari pinjaman (bunga) yang disyaratkan berkaitan dengan penggunaan utang, dan biaya atas modal sendiri (cost of equity) yang merupakan tingkat pengembalian yang diperlukan pemegang saham atas biaya penerbitan saham perusahaan. Dengan demikian, cost of debt dapat diartikan sebagai beban bunga yang harus dibayarkan oleh perusahaan dalam satu periode tertentu dibandingkan dengan jumlah rata-rata pinjaman yang berbunga dalam periode yang sama.

\subsection{Penurunan Tarif Pajak (Tax Cut Rate)}

Perubahan Undang-Undang Pajak terbaru di Indonesia terjadi tahun 2008 meliputi UndangUndang Ketentuan Umum dan Tata Cara Perpajakan (UU KUP), Undang-Undang Pajak Penghasilan (UU PPh), serta Undang-Undang Pajak Pertambahan Nilai Barang dan Jasa dan Pajak Penjualan atas Barang Mewah (UU PPN dan PPnBM). Hal ini diatur berdasarkan Aturan Pelaksanaan Ketentuan Pasal 4 Peraturan Pemerintah No. 81 Tahun 2007, UU No. 36 Tahun 2008 tentang Perubahan Keempat atas UU No. 7 Tahun 1983 tentang Pajak Penghasilan dan dipertegas dengan Peraturan Menteri Keuangan No. 238/PMK.03/2008.

Adapun pokok-pokok kebijakan dari perubahan UU Pajak Penghasilan tersebut diantaranya adalah sebagai berikut:

a. Bagi WP orang pribadi, tarif $\mathrm{PPh}$ tertinggi diturunkan dari 35\% menjadi 30\% dan menyederhanakan lapisan tarif dari 5 lapisan menjadi 4 lapisan, namun memperluas masing-masing lapisan penghasilan kena pajak (income bracket), yaitu lapisan tertinggi dari sebesar Rp 200 juta menjadi Rp 500 juta.

b. Bagi WP badan, tarif PPh yang semula terdiri dari 3 lapisan, yaitu 10\%, 15\% dan 30\% menjadi tarif tunggal $28 \%$ di tahun 2009 dan $25 \%$ tahun 2010. Selain itu, bagi WP badan yang telah go public diberikan pengurangan tarif $5 \%$ dari tarif normal dengan kriteria paling sedikit $40 \%$ saham dimiliki oleh masyarakat.

\subsection{Penelitian Terdahulu}

Adapun penelitian terdahulu yang diacu oleh penelitian ini seperti yang pada tabel 3 dibawah ini.

Tabel 3. Penelitian Terdahulu

\begin{tabular}{|c|c|c|c|}
\hline Peneliti & Variabel & Sampel & Hasil \\
\hline $\operatorname{Lim}(2011)$ & $\begin{array}{l}\text { 1. Cost of Debt }(\mathrm{Y}) \\
\text { 2. Tax Avoidance }(\mathrm{X}) \\
\text { 3. Kepemilikan } \\
\text { Institusional }(\mathrm{Z})\end{array}$ & $\begin{array}{l}5530 \text { sampel dari } \\
\text { perusahaan } \\
\text { manufaktur yang } \\
\text { terdaftar di Bursa } \\
\text { Efek Korea periode } \\
\text { 1994-2003 }\end{array}$ & $\begin{array}{l}\text { 1. Tax avoidance berpengaruh } \\
\text { negatif terhadap cost of debt } \\
\text { 2. Kepemilikan institusional } \\
\text { terbukti memperkuat pengaruh } \\
\text { tax avoidance terhadap cost of debt }\end{array}$ \\
\hline $\begin{array}{l}\text { Wijaya dan } \\
\text { Martani (2011) }\end{array}$ & $\begin{array}{l}\text { 1. Discretionary Accrual }(\mathrm{Y}) \\
\text { 2. Tax Shield }\left(\mathrm{X}_{1}\right) \\
\text { 3. Perencanaan Pajak }\left(\mathrm{X}_{2}\right) \\
\text { 4. Kewajiban Pajak } \\
\text { Tangguhan Bersih }\left(\mathrm{X}_{3}\right) \\
\text { 5. Earnings Pressure }\left(\mathrm{X}_{4}\right) \\
\text { 6. Tingkat Utang }\end{array}$ & $\begin{array}{l}322 \text { sampel dari } \\
\text { perusahaan } \\
\text { perbankan yang } \\
\text { terdaftar di BEI } \\
\text { periode } 2007-2009\end{array}$ & $\begin{array}{l}\text { 1. Perusahaan menunda } \\
\text { penghasilan (bersih) ke periode } \\
\text { yang tingkat pajaknya lebih } \\
\text { rendah dalam menanggapi } \\
\text { penurunan tarif pajak } \\
\text { penghasilan badan } \\
\text { 2. Perencanaan pajak berpengaruh }\end{array}$ \\
\hline
\end{tabular}




\begin{tabular}{|c|c|c|c|}
\hline Peneliti & Variabel & Sampel & Hasil \\
\hline & $\begin{array}{l}\text { Perusahaan }\left(\mathrm{X}_{5}\right) \\
\text { 7. Earnings Bath }\left(\mathrm{X}_{6}\right) \\
\text { 8. Ukuran Perusahaan }\left(\mathrm{X}_{7}\right) \\
\text { 9. Persentase Jumlah } \\
\text { Saham Disetor } \\
\text { Perusahaan yang } \\
\text { Diperdagangkan di BEI } \\
\left(\mathrm{X}_{8}\right)\end{array}$ & & $\begin{array}{l}\text { negatif terhadap discretionary } \\
\text { accrual (diterima) } \\
\text { 3. Kewajiban pajak tangguhan } \\
\text { bersih berpengaruh positif } \\
\text { terhadap discretionary accrual } \\
\text { (diterima) } \\
\text { 4. Earnings pressure berpengaruh } \\
\text { negatif terhadap discretionary } \\
\text { accrual (diterima) } \\
\text { 5. Tingkat utang perusahaan } \\
\text { berpengaruh positif terhadap } \\
\text { discretionary accrual (ditolak) } \\
\text { 6. Earning bath berpengaruh negatif } \\
\text { terhadap discretionary accrual } \\
\text { (ditolak) } \\
\text { 7. Ukuran perusahaan } \\
\text { berpengaruh negatif terhadap } \\
\text { discretionary accrual (ditolak) } \\
\text { 8. Persentase jumlah saham disetor } \\
\text { perusahaan yang } \\
\text { diperdagangkan di BEI } \\
\text { berpengaruh negatif terhadap } \\
\text { discretionary accrual (ditolak) }\end{array}$ \\
\hline $\begin{array}{l}\text { Masri dan } \\
\text { Martani (2012) }\end{array}$ & $\begin{array}{l}\text { 1. Cost of Debt }(\mathrm{Y}) \\
\text { 2. Tax Avoidance }(\mathrm{X}) \\
\text { 3. Perubahan Tarif Pajak } \\
\left.\text { ( } \mathrm{Z}_{1}\right) \\
\text { 4. Struktur Kepemilikan } \\
\text { Keluarga }\left(\mathrm{Z}_{2}\right)\end{array}$ & $\begin{array}{l}\text { 186 sampel } \\
\text { perusahaan } \\
\text { manufaktur yang } \\
\text { terdaftar di BEI } \\
\text { periode 2008-2010 }\end{array}$ & $\begin{array}{l}\text { 1. Tax avoidance berpengaruh } \\
\text { positif terhadap cost of debt } \\
\text { 2. Perubahan tarif pajak tidak } \\
\text { dapat memoderasi pengaruh tax } \\
\text { avoidance terhadap cost of debt } \\
\text { 3. Perusahaan keluarga } \\
\text { memperkuat pengaruh positif } \\
\text { tax avoidance terhadap cost of debt }\end{array}$ \\
\hline Rusydi (2013) & $\begin{array}{l}\text { 1. Aggressiveness Tax } \\
\quad \text { Avoidance }(\mathrm{Y}) \\
\text { 2. Firm Size }(\mathrm{X}) \\
\text { 3. Leverage }\left(\mathrm{Z}_{1}\right) \\
\text { 4. } \operatorname{ROA}\left(\mathrm{Z}_{2}\right)\end{array}$ & $\begin{array}{l}232 \text { sampel } \\
\text { perusahaan } \\
\text { manufaktur yang } \\
\text { terdaftar di BEI } \\
\text { periode 2010-2012 } \\
\end{array}$ & $\begin{array}{l}\text { Ukuran perusahaan tidak } \\
\text { berpengaruh terhadap aggressive } \\
\text { tax avoidance di Indonesia }\end{array}$ \\
\hline $\begin{array}{l}\text { Purwanti } \\
\text { (2014) }\end{array}$ & $\begin{array}{l}\text { 1. Cost of Debt }(Y) \\
\text { 2. Tax Avoidance }\left(X_{1}\right) \\
\text { 3. Perubahan tarif pajak } \\
\left(X_{2}\right)\end{array}$ & $\begin{array}{l}140 \text { sampel } \\
\text { perusahaan } \\
\text { manufaktur yang } \\
\text { terdaftar di BEI } \\
\text { periode 2008-2010 } \\
\end{array}$ & $\begin{array}{l}\text { 1. Tax avoidance tidak berpengaruh } \\
\text { signifikan terhadap cost of debt } \\
\text { 2. Perubahan tarif pajak tidak } \\
\text { mampu memoderasi pengaruh } \\
\text { tax avoidance terhadap cost of debt }\end{array}$ \\
\hline $\begin{array}{l}\text { Santosa dan } \\
\text { Kurniawan } \\
\text { (2016) }\end{array}$ & $\begin{array}{l}\text { 1. Cost of Debt }(\mathrm{Y}) \\
\text { 2. Tax Avoidance }(\mathrm{X})\end{array}$ & $\begin{array}{l}245 \text { sampel dari } \\
\text { perusahaan } \\
\text { manufaktur yang } \\
\text { terdaftar di BEI } \\
\text { periode } 2010-2014 \\
\end{array}$ & $\begin{array}{l}\text { Tax Avoidance memiliki pengaruh } \\
\text { positif signifikan terhadap cost of } \\
\text { debt }\end{array}$ \\
\hline $\begin{array}{l}\text { Koverman } \\
(2018)\end{array}$ & $\begin{array}{l}\text { 1. Cost of Debt }(\mathrm{Y}) \\
\text { 2. Tax Avoidance }(\mathrm{X}) \\
\text { 3. Tax Risk }(\mathrm{M})\end{array}$ & $\begin{array}{l}\text { 591 sampel dari } \\
\text { seluruh } \\
\text { perusahaan di } \\
\text { Eropa periode } \\
\text { 2012-2014 }\end{array}$ & $\begin{array}{l}\text { 1. Tax avoidance meningkatkan } \\
\text { kemampuan perusahaan untuk } \\
\text { melunasi utang } \\
\text { 2. Task risk berpengaruh signifikan } \\
\text { terhadap cost of debt perusahaan }\end{array}$ \\
\hline
\end{tabular}




\subsection{Desain Penelitian}

\begin{tabular}{|c|c|c|}
\hline $\begin{array}{c}\text { Tax Avoidance } \\
(X)\end{array}$ & $\mathrm{H}_{1}(+)$ \\
\cline { 2 - 2 } & $(Y)$
\end{tabular}

Gambar 1. Desain Penelitian

\subsection{Hipotesis Penelitian}

\subsubsection{Pengaruh Tax avoidance terhadap Cost of} debt

Menurut Teori Modigliani Miller Proposisi II, penggunaan utang dapat meningkatkan nilai perusahaan dengan adanya tax shield dalam utang, yaitu bunga pinjaman yang dapat digunakan sebagai pengurang pajak (tax deductible) yang akan berdampak pada meningkatnya pengembalian laba kepada investor, sehingga nilai perusahaan pun akan meningkat. Dengan demikian, dari sisi pajak akan lebih menguntungkan jika perusahaan membiayai investasinya dengan utang. Jadi, dapat disimpulkan, umumnya perusahaan dengan tingkat pajak yang tinggi akan cenderung melakukan penghindaran pajak dengan memanfaatkan deductible expense dari pinjaman (cost of debt), sehingga disinyalir akan memiliki utang yang lebih besar dengan tetap mempertimbangkan adanya penurunan tarif pajak badan. Sejalan dengan teori tersebut, penelitian Bayless dan Diltz (1994) membuktikan bahwa pengaruh penurunan tarif pajak badan akan turut menurunkan rasio utang perusahaan. Demikian pula penelitian Kovermann (2018) telah membuktikan bahwa tax avoidance justru berimplikasi terhadap peningkatan utang perusahaan dengan anggapan bahwa peningkatan utang akan memberikan konsekuensi terhadap meningkatnya kemampuan perusahaan dalam melunasi utang, sehingga turut juga meningkatkan kredibilitasnya sebagai kreditur. Oleh sebab itu, tax avoidance memotivasi perusahaan untuk meningkatkan utangnya demi mendapatkan manfaat pengurangan pajak dari bunga pinjaman yang diperoleh (cost of debt).

Berkaitan dengan ulasan teori dan hasil penelitian secara empiris dari peneliti sebelumnya, maka dapat dirumuskan hipotesis berikut:

$\mathrm{H}_{1}$ : Tax avoidance berpengaruh positif terhadap cost of debt

\section{RESEARCH METHOD}

\subsection{Jenis Penelitian}

Suatu penelitian yang dilakukan untuk menguji apakah satu atau beberapa variabel menyebabkan terjadinya perubahan pada variabel yang lain adalah jenis penelitian kuantitatif dengan pendekatan kausalitas (Sekaran dan Bougie, 2013).
Demikian juga, konteks penelitian ini bertujuan untuk menguji pengaruh tax avoidance (sebagai variabel independen) terhadap cost of debt (variabel dependen) di saat tarif pajak sudah turun ini merupakan penelitian kuantitatif dengan menganalisis sebab-akibat antara kedua variabel, dependen dan independen. Pengujian dilakukan dengan menganalisis data keuangan dari laporan tahunan perusahaan manufaktur yang terdaftar dalam Bursa Efek Indonesia.

\subsection{Populasi dan Sampel Penelitian}

Populasi dalam penelitian ini adalah seluruh perusahaan manufaktur yang terdaftar di Bursa Efek Indonesia. Pemilihan sampel menggunakan purposive sampling method, artinya sampel sengaja dipilih berdasarkan kriteria-kriteria tertentu agar dapat mewakili populasinya (Sekaran, 2006), maka kriteria dalam pemilihan sampel, yaitu:

1. Perusahaan manufaktur yang terdaftar di Bursa Efek Indonesia secara berturut-turut sejak 1 Januari 2012 hingga 31 Desember 2017 dengan pertimbangan perusahaan di tahuntahun tersebut dapat merepresentasikan tujuan penelitian dalam periode setelah tarif pajak penghasilan mengalami penurunan.

2. Perusahaan yang mempublikasikan annual report dan data keuangan yang lengkap selama tahun yang mencerminkan data setelah adanya penurunan tarif pajak penghasilan wajib pajak badan.

3. Perusahaan manufaktur yang terdaftar di Bursa Efek Indonesia yang tidak menggunakan mata uang selain rupiah, hal ini dikarenakan peneliti menghindari kebijakan Bank Indonesia (BI) sebagai pihak regulator (eksternal) dalam penetapan kurs. Hal ini dikarenakan konteks penelitian ini berupaya untuk menghindari pengaruh berbagai kebijakan eksternal sebagai disturbance (faktor pengganggu) yang dimungkinkan tidak mencerminkan kinerja perusahaan secara riil.

4. Perusahaan yang tidak melaporkan rugi dalam rentang tahun 2012 - 2017 dalam laporan keuangan tahunannya. Dengan pertimbangan bahwa perusahaan yang rugi tidak dapat mengajukan permohonan utang kepada pihak Bank, karena memiliki kredibilitas yang turun. 
Perusahaan dengan kondisi rugi, secara umum cenderung menggunakan cara lain untuk memperoleh keuntungan pajak di luar pengurangan dari bunga pinjaman, yaitu dengan menggunakan non-debt tax shield yang berupa tax loss carryforward. Sesuai dengan pasal 6 Ayat (1) huruf (2) berikut ini:

"Jika pengeluaran-pengeluaran yang diperkenankan berdasarkan ketentuan pada ayat (1) setelah dikurangkan dari penghasilan bruto didapat kerugian, kerugian tersebut dikompensasikan dengan penghasilan neto atau laba fiskal selama 5 (lima) tahun berturut-

turut dimulai sejak tahun berikutnya sesudah didapatnya kerugian tersebut."

Artinya, kerugian yang dialami perusahaan tersebut dapat dikompensasikan dengan penghasilan neto atau laba fiskal selama 5 tahun yang akan datang.

Berdasar kriteria tersebut, maka diperoleh populasi berjumlah 125 perusahaan, sedangkan jumlah perusahaan yang memenuhi kriteria sampel penelitian berjumlah 50 perusahaan. Sampel yang diperoleh ditunjukkan dalam tabel 4 , berikut in

Tabel 4. Kriteria Sampel Penelitian

\begin{tabular}{|c|l|c|}
\hline No. & \multicolumn{1}{|c|}{ Keterangan } & Jumlah \\
\hline 1 & Perusahaan manufaktur yang terdaftar di BEI & 125 \\
\hline 2 & $\begin{array}{l}\text { Perusahaan manufaktur yang tidak mempublikasikan laporan } \\
\text { keuangan tahunan secara lengkap }\end{array}$ & $(23)$ \\
\hline 3 & $\begin{array}{l}\text { Perusahaan manufaktur yang tidak menggunakan mata uang rupiah } \\
\text { dalam laporan keuangan tahunannya }\end{array}$ & $(27)$ \\
\hline 4 & $\begin{array}{l}\text { Perusahaan manufaktur yang melaporkan rugi dalam laporan } \\
\text { tahunannya }\end{array}$ & $(25)$ \\
\hline & Total Sampel yang digunakan & $\mathbf{5 0}$ \\
\hline
\end{tabular}

Sumber: Data laporan tahunan yang telah diolah

\subsection{Definisi dan Pengukuran Variabel} Penelitian

\subsubsection{Variabel Dependen}

Variabel dependen adalah variabel yang menjadi perhatian utama peneliti (Sekaran, 2006). Variabel dependen dalam penelitian ini adalah Cost of debt (COD) yang diukur mengacu pada penelitian Lim (2011) ataupun penelitian Pittman dan Fortin (2004), dengan mengubah pembilang yang semula adalah average short and long term debt menjadi total liabilitas yang dimiliki oleh perusahaan pada tahun pengamatan. Hal ini dikarenakan formula yang digunakan merepresentasi seberapa besar nilai beban bunga pinjaman terhadap total liabilitas perusahaan. Penghitungan Cost of debt (COD) dapat diformulasikan sebagai berikut:

$$
C O D=\frac{\sum \text { Interest Expense }_{t}}{\sum \text { Liability }_{t}}
$$

Keterangan:

Cost of debt (COD) : tarif bunga dalam utang/pinjaman

$\sum$ Interest Expenset : total beban bunga pinjaman

$\sum$ Liability $_{t}$ : total pinjaman
Total beban bunga pinjaman dapat diperoleh dari jumlah keseluruhan bunga pinjaman, baik yang berasal dari pinjaman jangka pendek maupun jangka panjang yang harus dibayarkan oleh perusahaan setiap tahunnya. Sedangkan total pinjaman merupakan jumlah seluruh pinjaman yang ada dalam perusahaan, baik pinjaman jangka pendek maupun jangka panjang.

\subsubsection{Variabel Independen}

Variabel independen (variabel bebas) adalah variabel yang memengaruhi baik secara positif atau negatif variabel dependen atau variabel bergantung (Sekaran, 2006). Dalam penelitian ini yang merupakan variabel independen adalah tax avoidance yang diukur dengan GAAP ETR mengacu pada penelitian Dyreng et al. (2008). GAAP ETR dapat dihitung dengan formula:

$$
\text { GAAP ETR }=\frac{{\text { Tax } \text { Expense }_{i, t}}_{\text {Pr } \text { etax }_{\text {Income }}}}{i, t}
$$

Keterangan:

a. GAAP ETR adalah effective tax rate berdasarkan pelaporan akuntansi keuangan yang berlaku

b. Tax expense adalah beban pajak penghasilan badan untuk perusahaan $i$ pada tahun $t$ berdasarkan laporan keuangan perusahaan. 
c. Pretax Income adalah pendapatan sebelum pajak untuk perusahaan $\mathrm{i}$ pada tahun $\mathrm{t}$ berdasarkan laporan keuangan perusahaan.

\subsection{Teknik Analisis Data}

\subsubsection{Uji Asumsi Klasik}

Uji asumsi klasik dilakukan untuk mengetahui apakah model regresi yang dipakai memenuhi asumsi Best Linear Unbiased Estimation (BLUE). Oleh sebab itu, 3 asumsi klasik yang utama dalam fokus analisis data penelitian ini adalah normalitas, autokorelasi, dan heteroskedastisitas, sehingga dibutuhkan suatu uji asumsi klasik sebelum akhirnya dibangun suatu model statistik yang fit.

\subsection{Uji Hipotesis}

\subsubsection{Uji Regresi Linear Sederhana}

Teknik analisis data yang digunakan untuk menguji hipotesis dalam penelitian ini adalah teknik regresi linear sederhana (simple regression analysis). Biaya Utang sebagai variabel dependen dengan menggunakan Cost of debt sebagai alat ukur, kemudian terdapat variabel independen, yaitu penghindaran pajak (tax avoidance) dengan alat ukur GAAP ETR. Dengan demikian, persamaan regresi linear berganda untuk pengujian hipotesis adalah sebagai berikut:

$$
\mathrm{COD}=\alpha+\beta_{1} \mathrm{GETR}+\varepsilon
$$

\section{DATA ANALYSIS AND DISCUSSION \\ 4.1 Hasil Uji Asumsi Klasik \\ 4.1.1 Hasil Uji Normalitas}

Uji normalitas bertujuan untuk mendeteksi distribusi data yang tidak mengarah pada suatu nilai tertentu (maksimum atau minimum), baik variabel dependen dan variabel independen, dimana keduanya mempersyaratkan berdistribusi normal (Ghozali, 2011). Untuk mendeteksinya dapat digunakan grafik Normal Probability Plot ataupun dengan uji Kolmogorov-Smirnov. Distribusi normal grafik Normal Probability Plots akan membentuk garis lurus diagonal dan ploting data akan dibandingkan dengan garis diagonal. Jika distribusi data adalah normal, maka data sesungguhnya akan mengikuti garis diagonalnya. Hasil analisis grafik Normal Probability Plot (gambar 2), sebagai berikut:
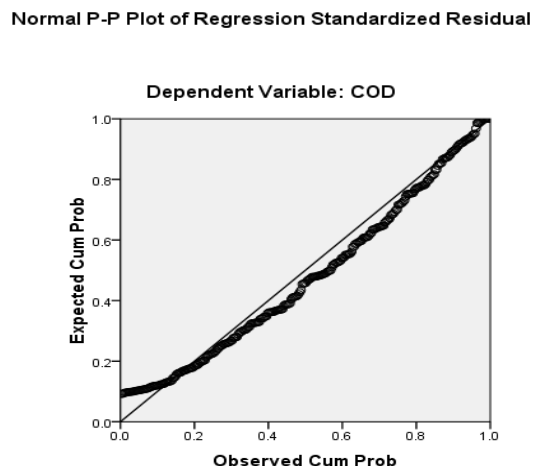

Sumber: Data diolah, 2018

Gambar 2. Hasil Uji Normal Probability Plot

Gambar 2, menunjukkan keseluruhan data dalam penelitian ini menyebar di sekitar garis diagonal, sehingga dapat dikatakan bahwa data terdistribusi normal. Mengacu pada uji normalitas Kolmogorov-Smirnov, maka peneliti melakukan uji pada kedua variabel, yaitu COD dan GETR dengan hasil sebagai berikut:

Tabel 5. Hasil Uji Kolmogorov-Smirnov

\begin{tabular}{|c|c|c|}
\hline Variabel & $\begin{array}{c}\text { Kolmogorov- } \\
\text { Smirnov Z }\end{array}$ & $\begin{array}{c}\text { Asymp. Sig. } \\
\text { (2-tailed) }\end{array}$ \\
\hline COD & 1,560 & 0,015 \\
\hline GETR & 5,736 & 0,000 \\
\hline
\end{tabular}

Sumber: Data diolah, 2018

Hasil uji (tabel 5) menunjukkan nilai Asymp. Sig. (2-tailed) < 0,05, sehingga dapat dikatakan sebaliknya bahwa data variabel Cost of debt dan Tax avoidance yang diukur dengan GAAP ETR tidak berdistribusi normal. Data yang tidak terdistribusi normal merepresentasi karakteristik perusahaan (manufaktur) di Indonesia yang cenderung mengarah pada perilaku secara individu (perusahaan) berdasar persepsi masing-masing dalam melakukan penghindaran pajak (tax avoidance) dan menganggap pajak yang wajib dibayar adalah beban yang jumlahnya material. Keputusan individu tersebut akan memberikan nilai COD dan GETR tidak mengarah pada besaran nilai tertentu (kecil atau besar), tetapi terdistribusi secara normal.

\subsection{Hasil Uji Autokorelasi}

Uji autokorelasi bertujuan menguji apakah dalam suatu model regresi linear ada korelasi antar kesalahan pengganggu (residual) pada periode $t$ dengan kesalahan pada periode $\mathrm{t}-1$ (sebelumnya). Dalam penelitian ini uji autokorelasi menggunakan 
uji Durbin-Watson (DW test), hasilnya (tabel 6), sebagai berikut:

Tabel 6. Hasil Uji Autokorelasi

\begin{tabular}{|c|c|c|c|}
\hline Model & Durbin-Watson & du & 4-du \\
\hline 1 & 1,898 & 1,585 & 1,503 \\
\hline
\end{tabular}

Sumber: Data diolah, 2018

Pengujian Durbin-Watson ini menggunakan derajat kepercayaan 5\% dengan jumlah sampel 50 perusahaan tiap tahun dan jumlah variabel bebas $=$ 1. Hasilnya menyatakan bahwa nilai DW adalah sebesar 1,898 tidak terletak diantara du dan 4-du, atau nilainya lebih besar daripada batas atas $(\mathrm{du})$, yaitu sebesar 1,503. Dengan demikian, dapat disimpulkan bahwa data dalam penelitian ini tidak memiliki autokorelasi positif.

\subsection{Hasil Uji Heteroskedastisitas}

Model regresi yang baik adalah model regresi yang terdapat kesamaan variance. Penelitian ini menggunakan metode grafik untuk mendeteksi ada tidaknya heteroskedastisitas. Metode ini dilakukan dengan melihat grafik plot antara nilai prediksi variabel dependen dengan residualnya. Hasil uji scatterplot dapat dilihat (gambar 3) sebagai berikut:

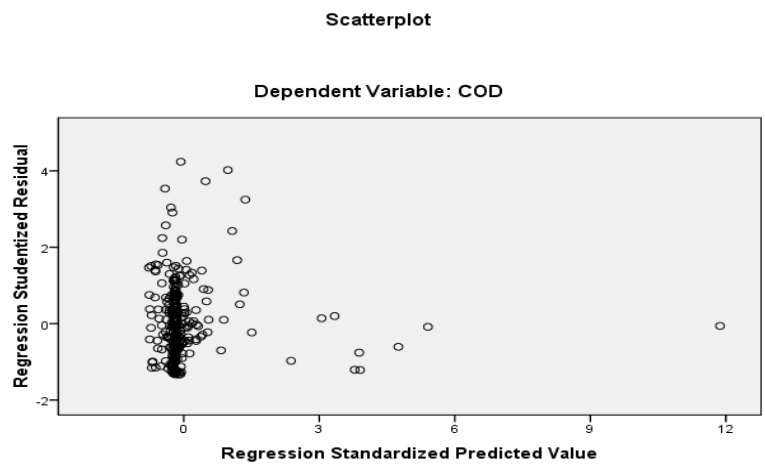

Sumber: Data diolah, 2018

Gambar 3. Hasil Uji Heteroskedastisitas

Dari hasil pengujian tersebut (gambar 3), menunjukkan bahwa grafik scatterplot membentuk pola tertentu yang teratur, sehingga mengindikasikan telah terjadi heteroskedastisitas. Data yang tidak homogen (varian yang tidak sama) ini terjadi dikarenakan dalam mengambil keputusan untuk melakukan tax avoidance dengan memanfaatkan beban pinjaman, tidak terlepas dari risiko yang harus dipertimbangkan. Beban pinjaman dapat muncul dari pinjaman jangka pendek maupun pinjaman jangka panjang yang memiliki tingkat risiko financial distress yang tidak sama. Dalam penelitian ini, pengukuran beban pinjaman menggunakan total beban pinjaman tanpa mengelompokkan pinjaman jangka pendek ataupun jangka panjang terlebih dahulu demi memperoleh data yang relevan mengenai keseluruhan beban pinjaman yang benar-benar harus dikeluarkan oleh perusahaan untuk tujuan penghindaran pajak.

\subsection{Hasil Uji Hipotesis}

\subsubsection{Hasil Uji Koefisien Determinasi $\left(R^{2}\right)$}

Koefisien Determinasi pada dasarnya digunakan untuk mengukur seberapa jauh masingmasing maupun keseluruhan variabel independen (dalam model regresi) mampu menjelaskan variasi variabel dependen. Nilainya antara nol dan satu. Jika nilai $\mathrm{R}^{2}$ cenderung untuk mengarah pada angka 0 (nol), artinya kemampuan variabel independen dalam menjelaskan variabel dependen amat terbatas, begitupun sebaliknya. Hasil pengujian ditunjukkan pada tabel 7 , berikut:

Tabel 7. Hasil Uji Koefisien Determinasi $\left(\mathbf{R}^{2}\right)$

\begin{tabular}{|c|c|c|c|}
\hline Model & $\mathbf{R}$ & R Square & Adjusted R Square \\
\hline 1 & 0,145 & 0,021 & 0,018 \\
\hline
\end{tabular}

Sumber: Data diolah, 2018

Berdasarkan data diatas, diketahui bahwa nilai Adjusted $R$ Square adalah sebesar 0,018 atau $1,8 \%$. Artinya, variabel Cost of debt dapat menjelaskan variabel Tax avoidance sebesar 1,8\%, sedangkan sisanya, yaitu sebesar $98,2 \%$ dijelaskan oleh variabel independen lain yang tidak digunakan dalam model regresi penelitian ini.

\subsubsection{Hasil Uji Statistik F}

Hasil uji statistik $\mathrm{F}$ dapat menunjukkan apakah semua variabel independen yang dimasukkan dalam model telah layak dalam menjelaskan fenomena yang diteliti. Adapun hasil dari uji statistik $\mathrm{F}$ dapat dilihat dalam tabel 8, berikut ini:

Tabel 8. Hasil Uji Statistik F

\begin{tabular}{|c|c|c|}
\hline Model & F & Sig. \\
\hline 1 & 6,364 & 0,012 \\
\hline
\end{tabular}

Sumber: Data diolah, 2018

Tabel 8 diatas menunjukkan nilai signifikansi dari uji statistik $\mathrm{F}$ adalah sebesar 0,012. Nilai sig, yaitu 0,012 < 0,05, maka Ha diterima, artinya model penelitian mampu memprediksi nilai observasinya, sehingga model estimasi (regresi) layak digunakan untuk menjelaskan maupun memprediksi fenomena yang diteliti. 


\subsubsection{Hasil Uji Statistik $t$}

Uji statistik $\mathrm{t}$ menunjukkan seberapa jauh pengaruh satu variabel independen terhadap variabel dependennya. Adapun hasil uji statistik $\mathrm{t}$ (tabel 9) sebagai berikut:

Tabel 9. Hasil Uji Statistik $\mathbf{t}$

\begin{tabular}{|c|c|c|}
\hline Model & t & Sig. \\
\hline (Constant) & 16,979 & 0,000 \\
\hline GETR & 2,523 & 0,012 \\
\hline
\end{tabular}

Sumber: Data diolah, 2018

Hasil uji statistik $t$ (tabel 9), menunjukkan bahwa nilai konstanta memiliki nilai signifikan $(0,000<0,05)$, artinya jika model tidak memiliki variabel independen (GETR) maka nilai tax avoidance akan berada pada 16,979. Begitupun, nilai GETR terbukti memiliki nilai $p$-value sebesar $0,012<$ 0,05 , yaitu $p$-value < nilai $(0,05)$, maka terbukti bahwa $\mathrm{H}_{1}$ diterima, yaitu tax avoidance berpengaruh secara nyata (signifikan) terhadap cost of debt. Artinya, dalam melakukan praktik penghindaran pajak, perusahaan memang cenderung meningkatkan jumlah utangnya demi memperoleh manfaat pengurangan pajak dari biaya bunga pinjaman yang dapat menjadi pengurang dari penghasilan kena pajak, meskipun saat ini tarif pajak badan sudah turun menjadi 25\% untuk berapapun laba perusahaan.

\subsubsection{Analisis Pengaruh Tax Avoidance Terhadap Cost of Debt}

Hasil dari pengujian hipotesis membuktikan bahwa $\mathrm{H}_{1}$ diterima, yaitu tax avoidance berpengaruh positif signifikan terhadap cost of debt, artinya semakin besar tingkat beban pajak yang ingin diturunkan oleh perusahaan (tax avoidance) akan mengakibatkan semakin bertambahnya utang demi memperoleh pengurangan pajak dari bunga pinjaman tersebut. Dengan demikian terlihat pula bahwa penghindaran pajak oleh perusahaan manufaktur pada periode 2012 - 2017 tetap dilakukan dengan memanfaatkan bunga pinjaman meskipun di periode tersebut sudah lama diberlakukan penurunan tarif pajak. Penelitian ini menunjukkan hasil yang sejalan dengan penelitian Masri dan Martani (2012), serta Kovermann (2018) yang berhasil membuktikan bahwa tax avoidance berpengaruh positif terhadap cost of debt.

\subsection{Implikasi Hasil Penelitian}

\subsubsection{Implikasi Teoritis}

Hasil dari penelitian ini berhasil membuktikan bahwa tax avoidance berpengaruh positif terhadap cost of debt turut memperkuat teori Modigliani
Miller yaitu Proposisi II yang menyatakan penggunaan utang dapat meningkatkan nilai perusahaan dengan adanya tax shield berupa bunga pinjaman sebagai pengurang pajak, sehingga akan meningkatkan laba. Selain itu, penelitian ini juga mendukung teori Psikologis Fiskal yang melihat motivasi wajib pajak dalam melakukan penghindaran pajak yang menganggap bahwa pajak yang harus dibayar adalah suatu beban yang akan mengurangi laba dan perusahaan (wajib pajak) tidak mendapatkan imbal balik secara langsung dari pembayaran pajak yang telah dilakukannya. Dari hasil penelitian juga terlihat bahwa wajib pajak masih melakukan penghindaran pajak pada tahun-tahun setelah tarif pajak turun menjadi 25\%. Bukti ini sekaligus merefleksi di satu pihak, yaitu wajib pajak masih memiliki motivasi yang rendah untuk membayar pajak, meskipun di pihak pemerintah telah berupaya membuat kebijakan positif, yaitu menurunkan tarif pajak badan demi meningkatkan kerjasama para pembayar pajak dengan pemerintah.

\subsubsection{Implikasi Praktis}

Secara praktis hasil penelitian ini telah membuktikan bahwa perusahaan-perusahaan manufaktur akan selalu melakukan manajemen pajaknya dengan memanfaatkan tax deductible expense dengan melakukan rekayasa pengurangan penghasilan menggunakan beban-beban yang diperkenankan oleh Undang-Undang Perpajakan demi memperoleh laba yang lebih besar dengan berbagai tujuan, meskipun tarif pajak penghasilan pajak badan sudah turun. Penggunaan bebanbeban tersebut seringkali dilakukan dengan meningkatkan beban yang berkaitan langsung dengan operasional perusahaan, seperti halnya beban bunga pinjaman.

\section{CONCLUSION, IMPLICATION, SUGGES- TION, AND LIMITATIONS}

\subsection{Kesimpulan}

Penelitian ini dilakukan untuk membuktikan pengaruh tax avoidance terhadap cost of debt pada perusahaan manufaktur dalam periode setelah adanya penurunan tarif pajak penghasilan badan. Data yang digunakan adalah laporan tahunan perusahaan manufaktur yang terdaftar di Bursa Efek Indonesia pada tahun 2012 sampai dengan tahun 2017 untuk menunjukkan tingkat penggunaan utang demi memperoleh manfaat pengurangan beban pajak yang berasal dari bunga pinjaman. 
Berdasarkan hasil pembahasan dan pengujian hipotesis, dapat disimpulkan bahwa tingkat beban utang pada perusahaan manufaktur masih cukup besar digunakan oleh perusahaan meskipun tarif pajak penghasilan badan sudah turun. Artinya, penelitian ini menghasilkan temuan bahwa penghindaran pajak (tax avoidance) selalu akan dilakukan oleh perusahaan. Di Indonesia, khususnya perusahaan di bidang manufaktur cenderung memanfaatkan beban bunga pinjaman sebagai alat untuk mengefisienkan beban pajak yang harus dibayarkan. Penelitian ini mendukung teori Modigliani-Miller Proposisi II dan teori Psikologis Fiskal. Selain itu, temuan dalam penelitian ini juga turut mendukung penelitian Dyreng et. al. (2008), Lim (2011), serta Masri dan Martani (2012) yang menyatakan bahwa perusahaan dalam melakukan praktik tax avoidance memang memanfaatkan kelemahan-kelemahan dalam hukum pajak, salah satunya adalah meningkatkan beban yang dapat dijadikan sebagai pengurang pajak menurut peraturan perpajakan.

Mengacu pada tujuan pemerintah untuk mendorong investasi dan economic sustainability yang belum tercapai, maka sebaiknya pembenahan Undang-Undang Perpajakan mengenai biaya-biaya yang dapat digunakan sebagai pengurang pajak oleh Dirjen Pajak dapat memperhatikan faktorfaktor yang dapat mempengaruhi keputusan perusahaan besar dalam merespon kebijakan pemerintah berikutnya. Selain itu, sebaiknya pemerintah juga mempertimbangkan kebijakan baru yang akan diterapkan, dalam hal ini penurunan tarif pajak penghasilan badan yang akan diturunkan lagi hingga menjadi 10\%, mengingat setelah tarif pajak penghasilan badan diturunkan menjadi $25 \%$ saat ini, ternyata perusahaan manufaktur masih memanfaatkan tax deductible expense untuk meminimalkan beban pajak penghasilannya. Tentu saja hal ini dapat menghambat tujuan pemerintah untuk menumbuhkan iklim usaha dalam mengoptimalkan penerimaan negara. Tarif pajak yang semakin kecil akan mengakibatkan total penerimaan negara juga semakin kecil, sehingga diharapkan pemerintah dapat menetapkan kebijakan lain yang dapat mengimbangi turunnya penerimaan negara dari sektor pajak.

\subsection{Keterbatasan dan Saran Penelitian}

Keterbatasan dalam penelitian ini adalah data perusahaan manufaktur yang ada di Indonesia tidak dapat tercakup seluruhnya untuk diteliti karena tidak semua perusahaan manufaktur telah go public, dan tidak semua perusahaan manufaktur mempublikasikan laporan tahunannya secara lengkap mulai dari tahun 2012 sampai dengan tahun 2017. Hal ini membatasi perolehan data peneliti, dengan demikian disarankan agar penelitian selanjutnya dapat menggunakan data seluruh perusahaan manufaktur di Indonesia apabila memiliki akses untuk mendapatkan data laporan tahunan seluruh perusahaan manufaktur, baik yang terdaftar di Bursa Efek Indonesia maupun yang belum, sehingga dapat memberikan hasil penelitian yang lebih akurat.

Selain itu, pada uji asumsi klasik, data ternyata terdistribusi tidak normal yang mengindikasikan karakteristik perusahaan (manufaktur) di Indonesia yang cenderung mengarah pada perilaku yang sama, yaitu melakukan penghindaran pajak (tax avoidance) karena menganggap pajak yang wajib dibayar adalah beban. Dan pada uji heteroskedastisitas, mengindikasikan telah terjadi heteroskedastisitas. Hal ini karena dalam mengambil keputusan untuk melakukan tax avoidance dengan memanfaatkan beban pinjaman, tidak terlepas dari risiko yang harus dipertimbangkan oleh perusahaan. Peneliti secara sengaja tidak membedakan beban pinjaman menurut lamanya masa utang perusahaan, karena ingin memperoleh data beban yang utuh dan benar-benar harus dikeluarkan oleh perusahaan. Dengan demikian, bagi peneliti selanjutnya dapat menggolongkan jenis pinjaman menurut jangka waktunya agar dapat ditelaah lebih lanjut jenis pinjaman mana yang digunakan untuk melakukan penghindaran pajak beserta dampaknya.

\section{REFERENCES}

Ambarukmi, K. T. dan Diana, R. 2017. Pengaruh Size, Leverage, Profitability, Capital Intnensity Ratio, dan Activity Ratio Terhadap Effective Tax Rate (ETR). E-Jurnal Ilmiah Riset Akuntansi. Vol. 6 No. 17.

Akerlof, G. A. 1982. Labor Contracts As Partial Gift Exchange. The Quarterly Journal of Economics. Vol. XCVII No.4.

Ardyansah, D. dan Zulaikha. 2014. Pengaruh Size, Leverage, Profitability, Capital Intensity Ratio dan Komisaris Independen Terhadap Effective Tax Rate (ETR). Diponegoro Journal of Accounting. Vol. 3 No. 2 p.1-9.

Bathala, C.T. dan Carlson, S.J. 1995. The 1986 Tax Reform Act and Strategic Leverage Decisions.Journal of Financial and Strategic Decisions. Vol. 8, No. 2 p.57. 
Bayless, E. M. dan Diltz, D. J. 1994. Securities Offerings and Capital Structure Theory. Journal of Business Finance and Accounting.

Brigham, E. F dan Houston, J. F. 2011. Financial Management. Yulianto, Ali A. (Penerjemah). Manajemen Keuangan. Edisi Kedelapan. Erlangga. Jakarta.

Dharma, N. B. S. dan Noviari, N. 2017. Pengaruh Corporate Social Responsibility dan Capital Intensity Terhadap Tax avoidance. E-Jurnal Akuntansi Universitas Udayana. Vol. 18.1 p.529-556.

Dyreng, H. 2008. The Effects of Managers on Corporate Tax avoidance. America: University of North Carolina.

Field, L. P. dan Frey, B. S. 2002. Deterrence and tax morale: how tax administrations and tax payers interact. OECD Papers. Vol. 3 No. 10 p.1-19.

Ghozali, I. 2009. Ekonometrika, Teori, Konsep dan Aplikasi Dengan SPSS 17. Badan Penerbit Universitas Diponegoro. Semarang.

Graham, J. R. dan Tucker, A. 2006. Tax shelters and corporate debt policy. Journal of Financial Economics. Vol. 81 p.563-594.

Kovermann, J.H. 2018. Tax avoidance, tax risk and the cost of debt in a bank-dominated economy. Managerial Auditing Journal. Vol. 33 pp. 683-699.

Lim, Y. 2011. Tax avoidance, cost of debt and shareholder activism: Evidence from Korea. Journal of Banking and Finance. No. 35 p. 456470.

Masri,I. dan Martani, D. 2012. Pengaruh Tax avoidance Terhadap Cost of debt. Jurnal Tidak Terakreditasi.

Miller, M. 1977. Debt and Taxes. The Journal of Finance. Vo. 32. No. 2 p.261-276.

Modigliani, F. dan Miller, M. 1963. Corporate Income Taxes and The Cost of Capital: a correction. The American Economic Review. p. 433-443.

Myers, S. C dan Majluf, N. S. 1984. Corporate Financing and Investment Decisions When Firms Have Information That Investor Do Not Have. Journal of Financial Economics. Vol. 13 p.187-221.

Peraturan Menteri Keuangan No. 169/PMK.010/2015 Tentang Penentuan Besarnya Perbandingan Antara Utang dan Modal Perusahaan untuk Keperluan Penghitungan Pajak Penghasilan.

Peraturan Menterik Keuangan No. 238/PMK.03/2008 Tentang Tata Cara
Pelaksanaan dan Pengawasan Pemberian Penurunan Tarif Bagi Wajib Pajak Badan Dalam Negeri yang Berbentuk Perseroan Terbatas.

Peraturan Pemerintah Republik Indonesia No. 81 Tahun 2007 Tentang Penurunan Tarif Pajak Penghasilan Bagi Wajib Pajak Badan Dalam Negeri yang Berbentuk Perseroan Terbatas.

Pittman, J. A. dan Fortin, S. 2004. Auditor choice and the cost of debt capital for newly public firms. Journal of Accounting and Economics. Vol. 37 p.113-136.

Pohan, C. A. 2013. Manajemen Perpajakan: Strategi Perencanaan Pajak dan Bisnis. Gramedia. Jakarta.

Pujiryansyah, R. dan Firmansyah, A. 2015. Pengaruh Leverage, Kompensasi Rugi Fiskal dan Manajemen Laba Terhadap Penghindaran Pajak. Jurnal Politeknik Keuangan Negara. STAN Indonesia.

Purwanti, N. 2014. Pengaruh Penghindaran Pajak Terhadap Biaya Hutang Pasca Perubahan Tarif Pajak Badan Pada Perusahaan Manufaktur yang Terdaftar di Bursa Efek Indonesia. Jurnal Akuntansi Indonesia. Vol. 3. No. 2. Hal. 113-128.

Rego, S. O. 2003. Tax avoidance activities of U.S. multinational firms. Contemporary Accounting Research. Vol. 20 No. 4 p.805-833.

Resmi, Siti. 2016. Perpajakan: Teori dan Kasus. Edisi 9. Buku 1. Jakarta. Salemba Empat.

Rusydi, M. K. 2013. Pengaruh Ukuran Perusahaan Terhadap Aggressive Tax avoidance di Indonesia. Jurnal Akuntansi Multiparadigma. Vol. 4 No. 2 p.322-329.

Rusydi, M. K. dan Martani, D. 2014. Pengaruh Struktur Kepemilikan Terhadap Aggressive Tax avoidance. Simposium Nasional Akuntansi XVII. 2014.

Santosa, J.E., dan Kurniawan, H. 2016. Analisis Pengaruh Tax Avoidance Terhadap Cost of Debt Pada Perusahaan Manufaktur yang Terdaftar di BEI Selama Periode 2010-2014. Jurnal MODUS. Vol. 28 (2): 139-154.

Santoso, S. 2007. Menguasai Statistik di Era Informasi dengan SPSS 15. PT. Elex Media Komputindo. Jakarta.

Schmolders, G. 1959. Fiscal Psychology: A New Branch of Public Finance. National Tax Journal. Vol. 12 No. 4 p.340-345.

Siegfried, J. 1972. The relationship between economic structure and the effect of political influence: Empirical evidence from the fedral 
corporation income tax program. Journal of University of Wilconsin.

Sekaran, U., dan Bougie, R. 2013. Research Methods for Business - A Skill Building Approach.5 $5^{\text {th }}$ Edition. USA.

Stiglitz, J. E. 1969. A Re-Examination of The Modigliani-Miller Theorem. Review Economics and Statistics. Vol. 59 p.784-793.

Swingly, C. dan Sukartha, I. M. 2015. Pengaruh Karakter Eksekutif, Komite Audit, Ukuran Perusahaan, Leverage, dan Sales Growth Pada Tax avoidance. E-Journal Akuntansi Universitas Udayana. Vol. 10 No.1 p.47-62.

Titman, S. dan Wessels, R. 1988. The Determinants of Capital Structure Choice. The Journal of Finance. Vol. 43 No.1 p.1-19.
Undang-Undang No. 36 Tahun 2008. 2008. Tentang perubahan keempat atas Undang-Undang No. 7 Tahun 1983 tentang Pajak Penghasilan.

Wijaya, M. dan Martani, D. 2011. Praktik Manajemen Laba Perusahaan Dalam Menanggapi Penurunan Tarif Pajak Sesuai UU No. 36 Tahun 2008. Simposium Nasional Akuntansi XIV. Aceh.

http://bisnis.liputan6.com/reas/2906371/resmiberakhir-di-31-maret-ini-hasil-tax-amnesty. Diakses pada Rabu, 8 November 2017. 